\title{
Mikroszatellita-instabilitás előfordulása, intratumoralis heterogenitása, prognosztikus és prediktív potenciálja primer colorectalis carcinomák és párosított májáttéteik sebészi kezelését követően
}

\author{
Ágoston Emese Irma dr. ${ }^{1}$ - Baranyai Zsolt dr. ${ }^{1}$ - Dede Kristóf dr. ${ }^{4}$ \\ Bodoky György dr. ${ }^{3}$. Kulka Janina dr. ${ }^{2}$ - Bursics Attila dr. ${ }^{4}$ \\ Harsányi László dr. ${ }^{1}$ - Szász A. Marcell dr. ${ }^{2}$
}

Semmelweis Egyetem, Általános Orvostudományi Kar, ${ }^{1}$ I. Sebészeti Klinika, ${ }^{2} I$ I. Patológiai Intézet, Budapest ${ }^{3}$ Egyesített Szt. István és Szt. László Kórház, Onkológiai Osztály, Budapest ${ }^{4}$ Fővárosi Önkormányzat Uzsoki Utcai Kórház, Sebészeti-Onkosebészeti Osztály, Budapest

\begin{abstract}
Bevezetés: A vastagbéldaganatokra jellemző genetikai instabilitás megnyilvánulhat több úton: kromoszomális instabilitás, mikroszatellita-instabilitás, illetve „CpG-island methylator phenotype”. Ezek pontosabb karakterizálásával a rendelkezésre álló kezelések elviekben optimalizálhatók lehetnek. Célkitüzés: A szerzők a mikroszatellita-instabilitás előfordulását, heterogenitását, prognosztikus és prediktív potenciálját vizsgálták 122 primer colontumor szisztematikusan szelektált régióiban és 69 párosított májmetasztázisban. Módszer: Szöveti multiblokkok kialakítása után az MLH1, MSH2, MSH6 és PMS2 kifejeződését vizsgálták immunhisztokémiai módszerrel. Eredmények: A betegek 11,5\%-a (14/122) rendelkezett mikroszatellita-instabil fenotípusú daganattal. A különböző tumorrégiók fehérjekifejeződésében nem volt jelentős különbség. A primer tumor-májmetasztázis párok esetében 20,2\%-ban a kettő más mismatch repair státusba volt sorolható. A relapsusmentes és teljes túlélést tekintve a mismatch repair státus nem volt prognosztikus. Az 5-fluorouracil-, oxaliplatin-, irinotecan-, bevacizumab-, cetuximab-, panitumumabterápia hatékonyságát tekintve mismatch repair státus nem volt prediktív a progressziómentes és teljes túlélés adatai alapján. Következtetések: A prognosztikus faktorok pontosabb meghatározása nagyobb esetszámú, pontosan szelektált vizsgálat keretében hatékonyabbá teheti a kezelés megválasztását. Orv. Hetil., 2015, 156(36), 1460-1471.
\end{abstract}

Kulcsszavak: colorectalis carcinoma, májmetasztázis, mikroszatellita-instabilitás

Occurrence, intratumoral heterogeneity, prognostic and predictive potential of microsatellite instability following surgical resection of primary colorectal carcinomas and corresponding liver metastases

Introduction: Besides clinicopathological parameters, molecular markers can be very important, and further characterize colorectal carcinomas into chromosomally unstable, microsatellite instable and "CqG-island methylator phenotype" groups. Aim: To study the frequency of microsatellite instability using immunohistochemical evaluation of MLH1, MSH2, MSH6 and PMS2 proteins in colorectal carcinoma. Method: 122 colorectal carcinomas as well as in 69 paired liver metastases were evaluated. Additionally, prognostic and predictive potential of mismatch repair status was tested. Results: Microsatellite instable phenotype was identified in 11.5\% (14/122) of the tumours. There were no differences regarding staining intensity of tumour regions. Mismatch repair status was discordant in primaries vs. metastases in $20.2 \%$. There was no difference in progression free- and overall survival according to mismatch repair 
status. The mismatch repair status was not predictive for survival within systemic therapy regimen groups. Conclusions: The subgroups of colorectal carcinomas could be evaluated in a larger and homogenised patient cohort to predict prognosis and response to therapy.

Keywords: colorectal cancer, liver metastasis, microsatellite instability

Ágoston, E. I., Baranyai, Zs., Dede, K., Bodoky, Gy., Kulka, J., Bursics, A., Harsányi, L., Szász, A. M. [Occurrence, intratumoral heterogeneity, prognostic and predictive potential of microsatellite instability following surgical resection of primary colorectal carcinomas and corresponding liver metastases]. Orv. Hetil., 2015, 156(36), 1460-1471.

(Beérkezett: 2015. május 21.; elfogadva: 2015. június 18.)

\section{Rövidítések}

5-FU = 5-fluorouracil; CIMP = CpG-sziget-metilációs fenotípus; CIN = kromoszomális instabilitás; $\mathrm{CRC}=$ colorectalis carcinoma; $\mathrm{EGFR}=$ epidermalis növekedési faktor receptor; EMEA = European Medicines Agency; FDA U.S. = Food and Drug Administration, United States; FOLFIRI = folinsav, 5-fluorouracil, irinotecan; FOLFOX = folinsav, 5-fluorouracil, oxaliplatin; KRAS = Kirsten patkány szarkóma virális onkogén homológ; LV = leucovorin; $\mathrm{mAC}=$ módosított Astler-Collerbeosztás; $\mathrm{MMR}=$ mismatch repair $; \mathrm{MLHI}=$ MutL homológ 1 , vastagbélrák, nem polyposis típus 2; MSH2 = MutS homológ 2 , vastagbélrák, nem polyposis típus 1; MSH6 = MutS homológ 6; MSI = mikroszatellita-instabilitás; PFS = progressziómentes túlélés; PMS2 = posztmeiotikus szegregációban emelkedett $2 ; \mathrm{RFS}=$ relapsusmentes túlélés; RR = válaszarány; OS = teljes túlélés; TNM = tumorméret, nyirokcsomóstátus, távoli áttét

A colorectalis daganat világszerte az egyik leggyakoribb daganatos halálok nőkben és férfiakban egyaránt [1]. A daganatok felismerése hazánkban leggyakrabban III-as stádiumban következik be, azonban ekkor már a távoli áttétek kialakulásának veszélye a tapasztalatok szerint fokozott. Az angiogenezisgátlás mellett az epidermalis növekedési faktor receptor (EGFR-) ellenes terápia a célzott kezelések alapja metasztatikus colorectalis carcinoma esetén. A klasszikus klinikai és patológiai paraméterek (életkor, nem, lokalizáció, reszekció radikalitása, tumorméret, nyirokcsomóstátus, stádium, Dukes- és módosított Astler-Coller-beosztás) mellett a molekuláris biológia fejlődésével egyre több lehetőség nyílik a daganatos progresszió során létrejövő azon génhibák és hibás géntermékek megismerésére, amelyek a daganatok keletkezésében, növekedésében és terjedésében kulcsfontosságú szerepet játszanak. A jövő kezelési stratégiája a daganatok molekuláris genetikai sajátosságainak minél pontosabb feltérképezése, a terápiás érzékenységet, illetve a prognózist előre jelző molekulák (biomarkerek) kimutatása és ezáltal „személyre szabott terápia” meghatározása.

A vastagbéldaganatokat genetikai instabilitás jellemzi, amely geno- és fenotípusosan megnyilvánulhat több úton is, mint például a mikroszatellita-instabilitás (MSI),

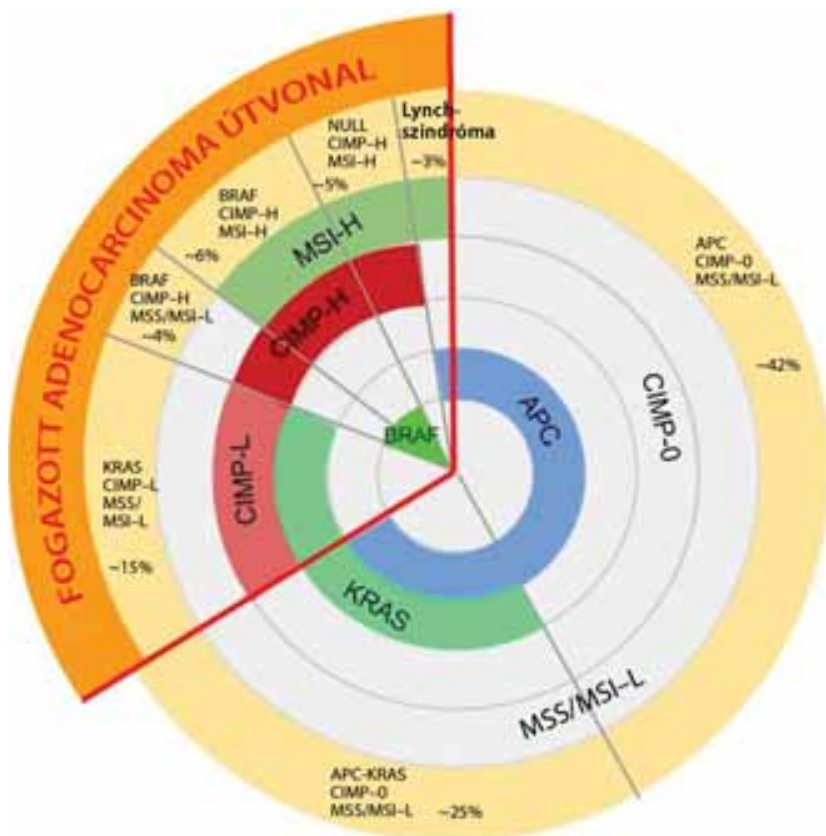

1. ábra $\mid$ A colorectalis daganatok hátterében feltételezett meghatározó molekuláris eltérések

kromoszomális instabilitás (CIN), illetve „CpG-island methylator phenotype" (CIMP) (1. ábra). Az egyes molekuláris eltérések bizonyos tumorokban együttesen is előfordulhatnak [2].

A mikroszatellita-instabilitás a genom instabilitásának egyik formája, amely a DNS nukleotidhibáinak felismerésére és kijavítására szolgáló mismatch repair (MMR) gének mutációja következtében jön létre [3]. A mikroszatellita-DNS-régiók 1-6 bázispárnyi szekvenciák, amelyek 8-50 kópiában ismétlődnek. Instabilitásuk a sporadikus daganatok között leggyakrabban a vastagbél daganataiban fordul elő, itt 10-15\%-ban mutatható ki [4]. Ezzel szemben az örökletes MMR-diszfunkcióval járó Lynch-szindrómás betegek túlnyomó többségében ez a génhiba áll a daganat kialakulásának hátterében, közel 90\%-ban [5, 6]. Az MSI-tumorokon belül a mikroszatellita-régiók érintettsége szempontjából két meghatározható csoport különül el: „MSI-high” (MSI-H, 
későbbiekben MSI), amikor a mikroszatellita-régiók 30\%-a vagy annál nagyobb aránya instabil, és „MSI-low” (MSI-L), amikor e régiók kevesebb mint 30\%-a instabil. A mikroszatellita-régiók stabilitása esetén a tumorokat mikroszatellita-stabilnak (MSS) tekintjük. Az MSI-Hdaganatok klinikai, patológiai és molekuláris jellemzői sporadikus vagy familiáris eredettől függetlenül különböznek az MSI-L- és MSS-daganatoktól [7]. Az MSItumorok MSS-tumorokhoz viszonyítva kevésbé agreszszívek és jobb prognózisúak [8,9], obes betegekben ritkábban [10], míg nókben gyakrabban fordulnak elő [11]. Az MSI-tumorok a flexura lienalistól inkább proximalisan helyezkednek el [9], sokszor alacsonyan differenciáltak [12], mucinosus [9] és kevert szövettani típusúak, és jellegzetes peri- és intratumoralis lymphoid sejtes infiltrációt mutatnak $[13,14]$. CD8+ lymphocytapopuláció jelenléte pozitív korrelációt mutat MSI-fenotípust kifejező tumorokkal, és egyes eredmények szerint hozzájárulhat a jobb prognózishoz [15]. Afroamerikai populációban az MSI-CRC gyakorisága hozzávetőleg fele a kaukázusi populációban találtnak, továbbá hiányzik a jellegzetes intraepithelialis CD8+ T-lymphocyta-infiltráció is, amely összefüggésben lehet e csoport roszszabb prognózisával ezen betegekben [15]. A III-as stádiumú és magas rizikójú II-es stádiumú colorectalis daganatok sebészi reszekciót követő adjuváns kemoterápiája 5-FU-alapú, amely a betegek túlélési esélyeit átlagosan 10-20\%-kal javítja [16]. Az irodalmi adatok még ellentmondásosak az MSI-daganatok optimális adjuváns kezelésének megválasztását illetően. A különböző vizsgálati eredmények alapján egyre inkább elfogadott, hogy II-es és valószínúleg a III-as stádiumú MSI vastagbélrákos betegek nem profitálnak az 5-FU-alapú kemoterápiából. Az elégtelen hibajavító rendszer mellett az 5-FUalapú adjuváns kemoterápia nem javítja a betegségmentes (RFS) vagy teljes túlélést (OS) [17], sőt csökkentheti is az RFS-t és az OS-t [18, 19].

Vizsgálatunkban az alábbi kérdésekre kerestünk választ:

1. Milyen gyakori az MSI progrediáló vastagbéldaganatos betegeink sebészeti mintáiban immunhisztokémiai meghatározás alapján?

2. Az MMR-markerek kifejeződésüket tekintve a primer tumorok különböző régióiban és a nyirokcsomómetasztázisokban mutatnak-e eltérést?

3. Lévén az MSI-tumorok irodalmi adatok alapján kevésbé agresszívek, a primer tumorok és sebészileg reszekált májáttéteik MMR-státusa megegyezik-e?

4. Beteganyagunkban milyen a rendelkezésre álló klinikopatológiai faktorok prediktív potenciálja?

5. Az MMR-státus prognosztikus-e betegeink betegségmentes és teljes túlélését tekintve a sebészi reszekciót követően?

6. Az MMR-státusnak van-e prediktív értéke az 5-FUalapú (oxaliplatint vagy irinotecant is tartalmazó) vagy a célzott biológiai kezeléssel kiegészített (bevacizumab vagy cetuximab, vagy panitumumab) kemoterápiás kezelések esetén?

7. A II-es és III-as stádiumú MSI vastagbéldaganatok 5-FU-alapú kezelésre eltérően reagálnak-e, illetve a II-es stádiumú betegek kimenetele 5-FU-kezelés után kedvezőtlenül alakul-e azonos stádiumú MSS-tumorokhoz viszonyítva?

\section{Betegek és módszer}

A vizsgálatba 122 beteget vontunk be a regionális kutatási etikai bizottság jóváhagyásával (IKEB \#207/11). A Semmelweis Egyetem (SE) I. Sebészeti Klinikáján került műtétre 89 beteg, tumoraik feldolgozása és a KRASstátus meghatározása az SE II. Patológiai Intézetben történt. A posztoperatív onkológiai kezelés az Egyesített Szt. István és Szt. László Kórház Onkológiai Osztályán zajlott. 33 beteg cetuximab-, 21 beteg bevacizumab- és 2 beteg panitumumabkezelést is kapott a kemoterápia mellett első, második és többedik vonalban. Az előrehaladott (idővel metasztázist képző) tumorok között 61 KRAS vad típusú mellett 28 KRAS-mutáns szerepelt. 69 beteg esetében vizsgáltuk párosított távoli áttéteiket is, mert a májmetasztázisukat is ugyanazon intézetben távolították el (SE I. Sebészeti Klinika). Kontrollcsoportként 33 beteget vizsgáltunk, akik az Uzsoki Utcai Kórház Sebészeti-Onkosebészeti Osztályán kerültek operációra, és minimum 5 éves betegségmentes túlélők, valamint ezen idő alatt nem alakult ki náluk sem lokális relapsus, sem távoli áttét (KRAS-, illetve BRAF-státusukat nem ismertük).

A betegek formalinban fixált és paraffinba ágyazott (FFPE) mintáiból szöveti multiblokkot (TMA) készítettünk (Tissue Microarray Builder, Hisztopatológia Kft., Pécs). Minden daganatból 2, esetenként 3 darab $2 \mathrm{~mm}$ átmérőjü részletet vizsgáltunk (összesen 265 hengert). Immunhisztokémiai eljárással Ventana Benchmark XT automatában a mikroszatellita-instabilitás jellemzésére MLH1-, MSH2-, MSH6- és PMS2-reakciót végeztünk. $\mathrm{Az}$ alkalmazott antitesteket az 1 . táblázat részletezi. A metszeteket Pannoramic 250beta metszetszkenner segítségével digitalizáltuk, és Pannoramic Viewer 1.15.2 TMA modul segítségével értékeltük az alábbi séma szerint: intenzitás (0-3), frekvencia (0-5) (3DHistech Kft., Budapest). A statisztikai értékelést SPSS 17.0 szoftverrel végeztük (SPSS Inc., Chicago, IL, Amerikai Egyesült Államok). A nemparametrikus változókat Fisher-féle eg-

1. táblázat | A vizsgálatban alkalmazott elsődleges antitestek és részleteik

\begin{tabular}{llllll}
\hline Antitest & Klón & Azonosító & Gyártó & Program & Hígítás \\
\hline MLH1 & G168-728 & $760-4264$ & Ventana & 864 & Ready-to-use \\
MSH2 & G219-1129 & $760-4265$ & Ventana & 880 & Ready-to-use \\
MSH6 & & $790-4455$ & Ventana & 866 & Ready-to-use \\
PMS2 & EPR3947 & $760-4531$ & Ventana & 879 & Ready-to-use \\
\hline
\end{tabular}


zakt teszttel hasonlítottuk össze. A prognosztikus és prediktív vizsgálatokat Kaplan-Meier-analízissel végeztük, amelyhez log-rank statisztikai támogatást alkalmaztunk.

\section{Eredmények}

\section{Az MSI-tumorok gyakorisága immunhisztokémiai meghatározás alapján}

14 tumor mutatott MSI-fenotípust: egyszeres markervesztést mutatott az összes tumor 7,8\%-a, kétszerest $2,6 \%$ és háromszorost $0,9 \%$ a 122 daganatból. A daganatok $88,5 \%$-a $(108 / 122)$ valamilyen mértékben mind a négy markert kifejezte (2. ábra).

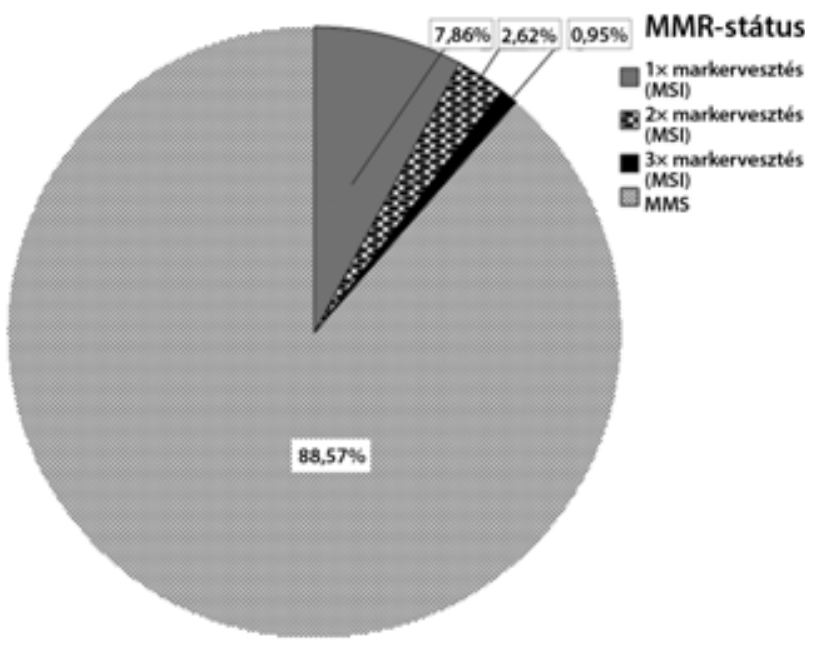

2. ábra A tumorok megoszlása az MSI-státus szerint: $88,5 \%$ MSS és
$11,5 \%$ MSI

\section{Az MSI-markerek kifejezódése}

a primer tumorok különbözö régióiban és nyirokcsomó-metasztázisokban

56 beteg sebészeti mintáiban vizsgáltuk részletesen a primer colorectalis tumor különböző régióit. A normál colon, normál tumor határ, a daganat fő tömege, az invazív front és az esetleges nyirokcsomóáttétben elhelyezkedő daganatos területeket összesen 265 régióban tudtuk elemezni (2. táblázat). Az MSI-markerek kifejeződésében intenzitásbeli különbségek ugyan látszottak, de a rele-

2. táblázat $\mid$ A tumorok egyes régióiban $(\mathrm{n}=265)$ kifejeződő markerek alapján az MSI-státus állandónak bizonyult $(\mathrm{p}=0,873)$

\begin{tabular}{lccccc}
\hline & Normál & $\begin{array}{c}\text { Tumor- } \\
\text { határ }\end{array}$ & $\begin{array}{c}\text { Fó } \\
\text { tumor- } \\
\text { tömeg }\end{array}$ & $\begin{array}{c}\text { Invazív } \\
\text { front }\end{array}$ & $\begin{array}{c}\text { Nyirok- } \\
\text { csomó }\end{array}$ \\
\hline MSS & 42 & 41 & 79 & 67 & 17 \\
MSI & 1 & 3 & 6 & 6 & 1 \\
Összesen & 43 & 44 & 85 & 73 & 18 \\
\hline
\end{tabular}
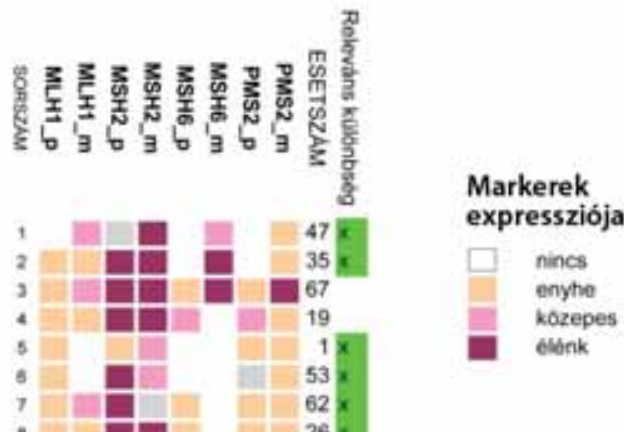

Markerek

expressziója

nincs

kozepes

chonk 

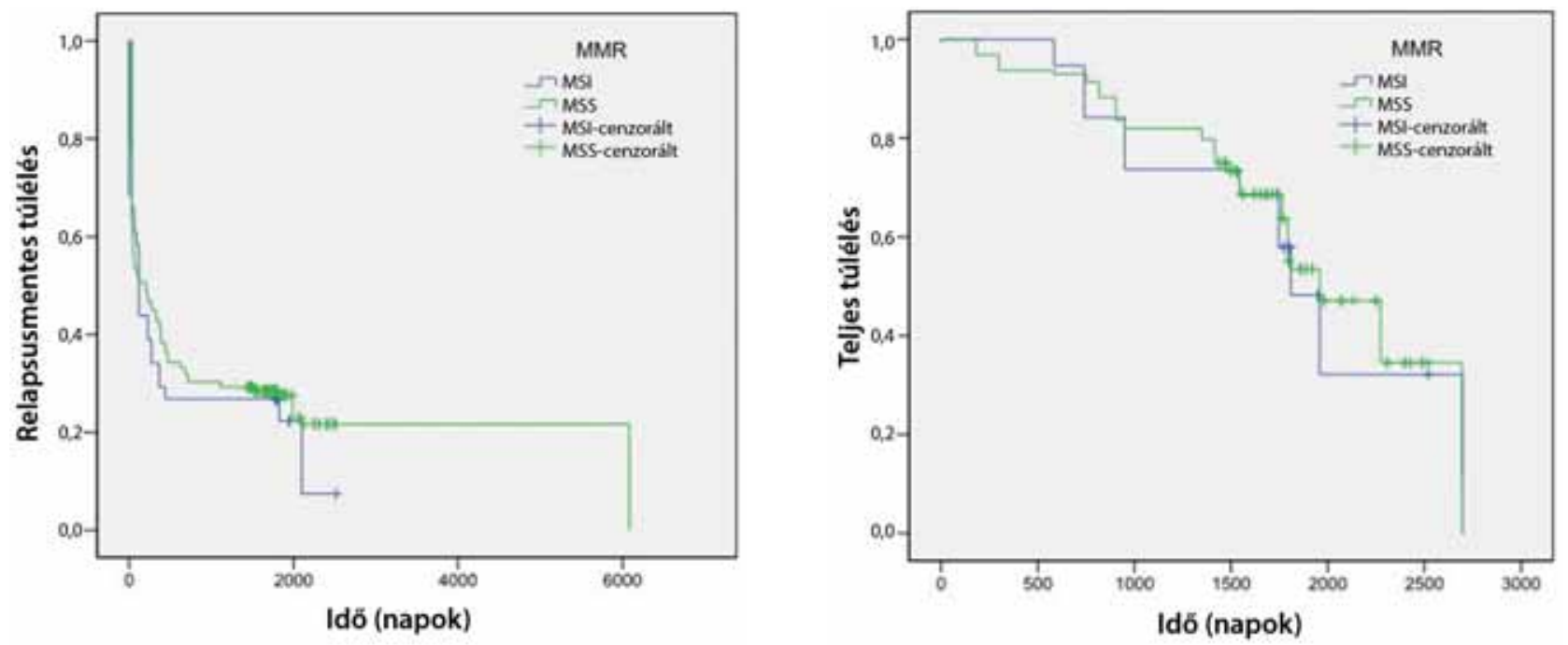

4. ábra | Az MSI- és MSS-tumorok relapsusmentes (bal) és teljes (jobb) túlélése között nem volt jelentős különbség

váns különbségek (az adott marker egyértelmú eltúnése/megjelenése) statisztikai értékelése során nem volt különbség az egyes területek között az egyes tumorok különböző régióinak, illetve ezek és a nyirokcsomóáttétek összehasonlításában $(\mathrm{p}=0,873)$.

\section{A primer tumorok és májáttéteik MSI-státusának összevetése}

69 beteg esetében vizsgáltuk a primer tumor és a hozzá tartozó májáttét MSI-státusát. Ebben a vizsgálatban is az

3. táblázat |A prognosztikus vizsgálatba bevont betegek $(\mathrm{n}=122)$ klinikopatológiai tulajdonságai

\begin{tabular}{|c|c|c|}
\hline \multirow[t]{2}{*}{$\mathrm{Nem}$} & Férfi & 68 \\
\hline & Nő & 54 \\
\hline \multicolumn{2}{|c|}{ Életkor $($ Átlag \pm SD $)$} & $68,3 \pm 10,7$ \\
\hline \multirow[t]{4}{*}{ Grade } & 1 & 3 \\
\hline & 2 & 78 \\
\hline & 3 & 24 \\
\hline & Nem ismert & 13 \\
\hline \multirow[t]{5}{*}{ Dukes } & A & 8 \\
\hline & B & 37 \\
\hline & C & 51 \\
\hline & $\mathrm{D}$ & 21 \\
\hline & Nem ismert & 3 \\
\hline \multirow[t]{5}{*}{ Stádium } & 1 & 11 \\
\hline & 2 & 36 \\
\hline & 3 & 50 \\
\hline & 4 & 21 \\
\hline & Nem ismert & 4 \\
\hline
\end{tabular}

adott marker egyértelmú eltúnése vagy megjelenése került statisztikai elemzésre. 14 (20,2\%) esetben releváns különbséget igazoltunk, amely alapján a primer tumor és a metasztázis más MMR-státusba volt sorolható (3. ábra).

\section{Klinikopatológiai faktorok és prediktín potenciáljuk}

A vizsgált betegek és tumoraik klinikopatológiai jellemzőit a 3. táblázat mutatja. A relapsusmentes túlélés (RFS) tekintetében a Dukes beosztás/stádium egyaránt jelentős elörejelző képességgel rendelkezett $(\mathrm{p}=0,001)$. Az egyes faktorok az OS tekintetében leginkább tendenciát mutattak, de a stádium jelentős prognosztikus potenciált mutatott ( $\mathrm{p}=0,009)$. A lokalizáció (bal vagy jobb colonfél) tekintetében megállapítható volt, hogy az RFS $(\mathrm{p}=0,275)$, PFS $(\mathrm{p}=0,072)$ és OS $(\mathrm{p}=0,227)$ tekintetében is csak tendencia érvényesül, amely szerint a legkedvezőb kimenetellel a balcolonfél-tumorral rendelkező betegek rendelkeztek, őket követték a rectum-, majd a jobbcolonfél-daganatos betegek. A daganatok lokalizációját és sebészi kezelését illetően nem mutatkozott jelentős túlélésbeli különbség: RFS $(\mathrm{p}=0,257)$ és OS $(\mathrm{p}=0,765)$.

\section{Az MSI-státus prognosztikus értéke a relapsusmentes és teljes túlélést tekintve a sebészi reszekciót köpetôen}

A 122 betegnél az RFS és OS tekintetében az MMRstátus vizsgálatunkban nem volt prognosztikus ( $\mathrm{p} /$ $\mathrm{RFS} /=0,437, \mathrm{p} / \mathrm{OS} /=0,907)(4$ ábra) . 
A betegek MMR-státus alapján az alábbi kezelési összetevőket kapták

\begin{tabular}{l|l|lc|l}
\hline \multicolumn{2}{c|}{} & \multicolumn{2}{|c}{ MSI } & \multirow{2}{*}{ Osszes } \\
\cline { 3 - 4 } \multicolumn{2}{c|}{} & Nem & Igen & \\
\hline \multirow{3}{*}{5 -FU } & Nem & 26 & 4 & 30 \\
& Igen & 57 & 10 & 67 \\
\hline Összes & 83 & 14 & 97
\end{tabular}

\begin{tabular}{l|l|ll|l}
\hline \multicolumn{2}{c|}{} & \multicolumn{2}{|c}{ MSI } & \multirow{2}{*}{ Összes } \\
\cline { 3 - 4 } \multicolumn{2}{c|}{} & Nem & Igen & \\
\hline \multirow{3}{*}{ Oxaliplatin } & Nem & 40 & 4 & 44 \\
& Igen & 43 & 10 & 53 \\
\hline \multicolumn{2}{l|}{ Összes } & 83 & 14 & 97
\end{tabular}

\begin{tabular}{l|l|lc|l}
\hline \multicolumn{2}{c|}{} & \multicolumn{2}{|c}{ MSI } & \multirow{2}{*}{ Összes } \\
\cline { 3 - 4 } \multicolumn{2}{c|}{} & Nem & Igen & \\
\hline \multirow{3}{*}{ Irinotecan } & Nem & 52 & 6 & 58 \\
& Igen & 31 & 8 & 39 \\
\hline \multicolumn{1}{l}{ Összes } & 83 & 14 & 97
\end{tabular}

\begin{tabular}{l|l|lc|l}
\hline \multicolumn{2}{c|}{} & \multicolumn{2}{|c}{ MSI } & \multirow{2}{*}{ Összes } \\
\cline { 3 - 4 } \multicolumn{2}{c|}{} & Nem & Igen & \\
\hline \multirow{3}{*}{ Bevacizumab } & Nem & 55 & 11 & 66 \\
& Igen & 28 & 3 & 31 \\
\hline \multicolumn{2}{l|}{ Összes } & 83 & 14 & 97 \\
\hline
\end{tabular}

\begin{tabular}{l|l|lc|l}
\hline \multicolumn{2}{l|}{} & \multicolumn{2}{|c}{ MSI } & \multirow{2}{*}{ Összes } \\
\cline { 3 - 4 } \multicolumn{2}{l|}{} & Nem & Igen & \\
\hline \multirow{2}{*}{ Cetuximab } & Nem & 67 & 6 & 73 \\
& Igen & 16 & 8 & 24 \\
\hline \multicolumn{2}{l|}{ Összes } & 83 & 14 & 97 \\
\hline
\end{tabular}

\begin{tabular}{l|l|lc|l}
\hline \multicolumn{2}{c|}{} & \multicolumn{2}{|c}{ MSI } & \multirow{2}{*}{ Összes } \\
\cline { 3 - 4 } \multicolumn{2}{c|}{} & Nem & Igen & \\
\hline \multirow{2}{*}{ Panitumumab } & Nem & 79 & 10 & 89 \\
& Igen & 4 & 4 & 8 \\
\hline \multicolumn{2}{l|}{ Összes } & 83 & 14 & 97 \\
\hline
\end{tabular}

\section{Az MSI-státus prediktín potenciálja az adott szisztémás kezelésre}

97 betegnél vizsgáltuk a posztoperatív kezelés és a molekuláris eredmények összefüggéseit (4. táblázat). A teljes túlélést vizsgálva az 5-FU-tartalmú kezelések esetén az MSI-státus nem volt prediktív ( $\mathrm{p}=0,968$ ), és hasonló eredményeket kaptunk az oxaliplatin $(\mathrm{p}=0,936)$, az irinotecan $(p=0,609)$, a bevacizumab $(p=0,561)$, a cetuximab $(\mathrm{p}=0,755)$, a panitumumab $(\mathrm{p}=0,617)$ esetében is $(5 . a ́ b r a)$. A progressziómentes túlélés tekintetében az oxaliplatin- $(\mathrm{p}=0,897)$, irinotecan- $(\mathrm{p}=0,961)$, bevaci- zumab- $(\mathrm{p}=0,946)$, cetuximab- $(\mathrm{p}=0,910)$, panitumumab- $(\mathrm{p}=0,95 \mathrm{l})$ kezelésre sem volt az MSI-státus prediktív (6. ábra).

\section{A II-es és III-as stádiumú MSI vastagbéldaganatok 5-FU-alapú kezelésre adott válasza}

A vizsgálatokat elvégeztük külön a II-es és III-as stádiumú betegeinkben, arra a kérdésre keresve a választ, hogy az MSI vastagbéldaganatok 5-FU-alapú kezelésre ezen stádiumokban eltéróen reagálnak-e, illetve a II-es stádiumú betegek esélye 5-FU-kezelés után kedvezőtlenül alakul-e. Mindössze 12 II-es stádiumú tumoros beteget tudtunk bevonni a vizsgálatba, akik 5-FU-alapú kezelést is kaptak. Ezen vizsgálatunkban sem a relapsusmentes, sem a teljes túlélés tekintetében nem tudtunk statisztikai különbséget kimutatni (7. A és B ábra). Hasonlóan alakultak az eredmények, amikor a 35 III-as stádiumú esetet elemeztük (7. Cés Dábra).

\section{Megbeszélés}

A daganatok klasszikus klinikopatológiai változói közül ma is releváns információk nyerhetők a betegek várható túlélésének megítélésére. Az egyes kezelési csoportokban azonban - vélhetôen a terápia hatásossága következtében - már a daganatok biológiai viselkedését tükröző rutinfaktorok múköóése árnyalódik. A colorectalis daganat genetikai heterogenitásának feltérképezése - mind etiológiáját, mind pedig az adjuváns terápiára adott válaszát illetően is - számos vizsgálat tárgyát képezi. A megbízható prognosztikus faktorok meghatározására kiterjesztett, igen nagyszámú beteganyag vagy szoros klinikai vizsgálat keretein belül nyílhat optimális lehetőség. Az MMR-rendszer jelentősége régóta ismert, mint a colorectalis carcinogenesis egyik fontos mechanizmusa [20]. Az MMR-gének öröklött mutációja HNPCC-szindróma (Lynch-szindróma) néven ismert, az érintett egyénekben kialakuló daganatok többnyire jellegzetes lokalizációt és szöveti képet mutatnak [21, 22]. Ugyancsak ismert, hogy ezen daganatok prognózisa is eltér (általában kedvezőbb) a hasonló lokalizációjú és stádiumú sporadikus daganatokétól [23]. Az MMR-rendszer meghibásodása sporadikus vastagbéldaganatokban is bekövetkezhet, az irodalmi adatok szerint sporadikus mikroszatellita-instabilitás a vastagbélrákok körülbelül $15 \%$-ában mutatható ki [4]. Munkánkban 122, vastagbélrákban szenvedő beteg sebészeti mintáit dolgoztuk fel, és tudomásunk szerint korábban részben még nem vizsgált kérdésekre is válaszokat kerestünk. A primer daganatok különböző területeit és esetleges nyirokcsomóáttéteit (56 beteg) és primer tumorokhoz párosított reszekált májáttéteket $(69$ beteg) vizsgáltunk MSI-t jelző fehérjék (MLH1, MSH2, MSH6, PMS) expressziója szempontjából annak tisztázására, hogy kimutatható-e intratumoralis, illetve a pri- 
mer daganat-metasztázis párok esetén egy betegen belül heterogenitás ezen fehérjék kifejeződésében. Beteganyagunkban 14 tumor (11,4\%) mutatott MSI-fenotípust, amely arány az irodalmi adatokkal összhangban van [24]. A tumorrégiók elemzése során a normál colon, normál tumor határ, a daganat fó tömege, az invazív front és az esetleges nyirokcsomóáttétben elhelyezkedő daganatos területek MSI-marker-kifejeződésében intenzitásbeli különbségek látszottak, de nem volt statisztikailag jelentős eltérés az egyes területek között, valamint a primer tumorok és nyirokcsomóáttéteik között. A szakirodalomban idáig kevés olyan tanulmányt találtunk, amely hozzánk hasonló kérdést vizsgált colorectalis [25,
26] vagy más carcinomában [27]. A mintavétel szempontjából megállapíthatjuk, hogy az MSI-státus a colorectalis tumor bármely területéról származó anyagból meghatározható.

Egyelőre egyértelmű összefüggés nem vonható le arra vonatkozóan, hogy a mikroszatellita-instabilitás a tumorgenezis korai vagy késői szakaszára tehető, illetve hogy lenne-e egy meghatározott génmutációs kaszkád az MSI colorectalis daganatok carcinogenesise során. Ezen eltérések véletlenszerú halmozódása feltételezhető, amelynek hátterében egy „mutator fenotípus” állhat [26]. A primer tumorokat májáttéteikkel összevetve 20,2\%-ban volt olyan különbség a daganatokban, amely

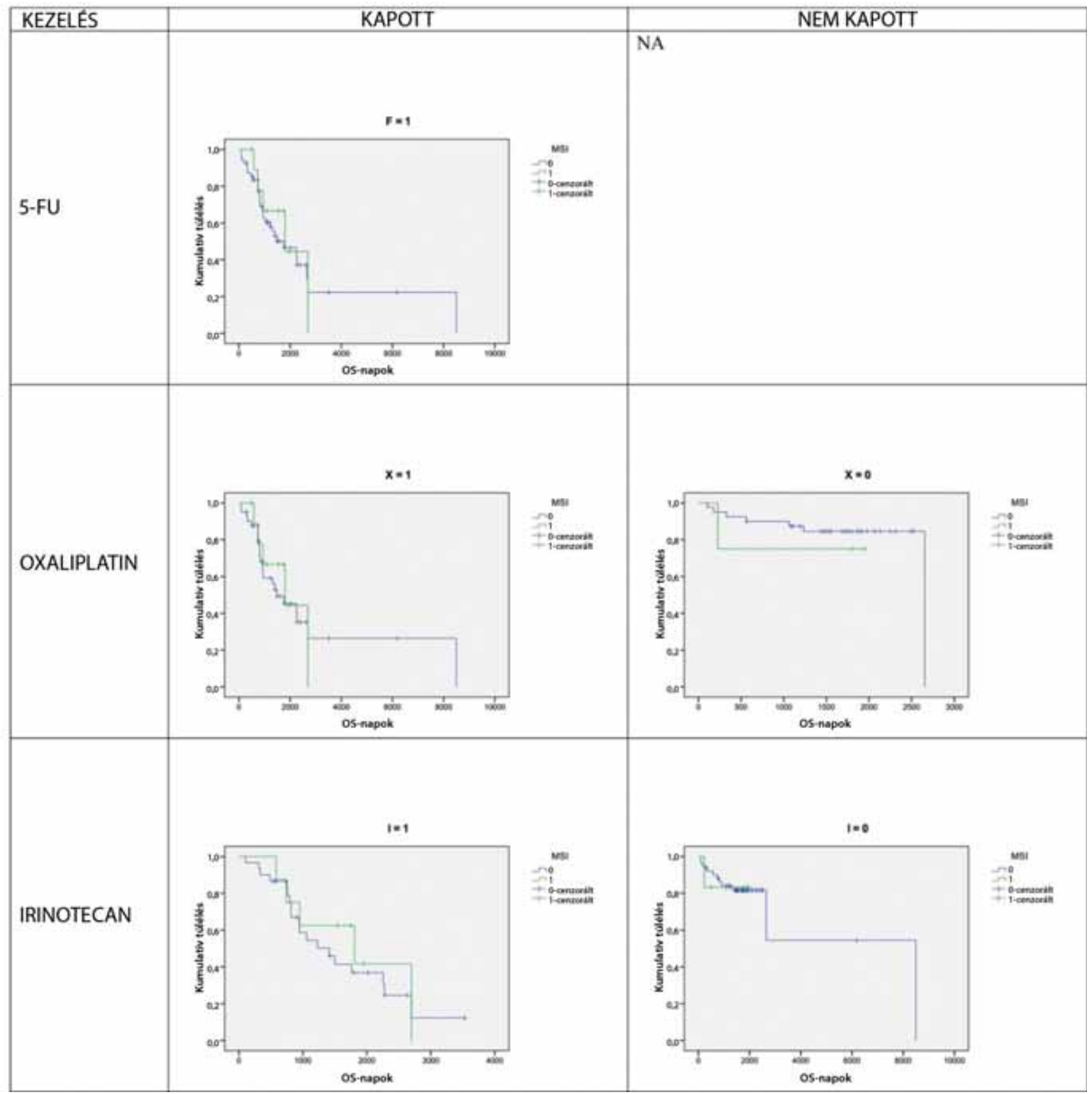

5. ábra

| Kezelés szerinti prediktív összehasonlítások az MMR-státustól függően 


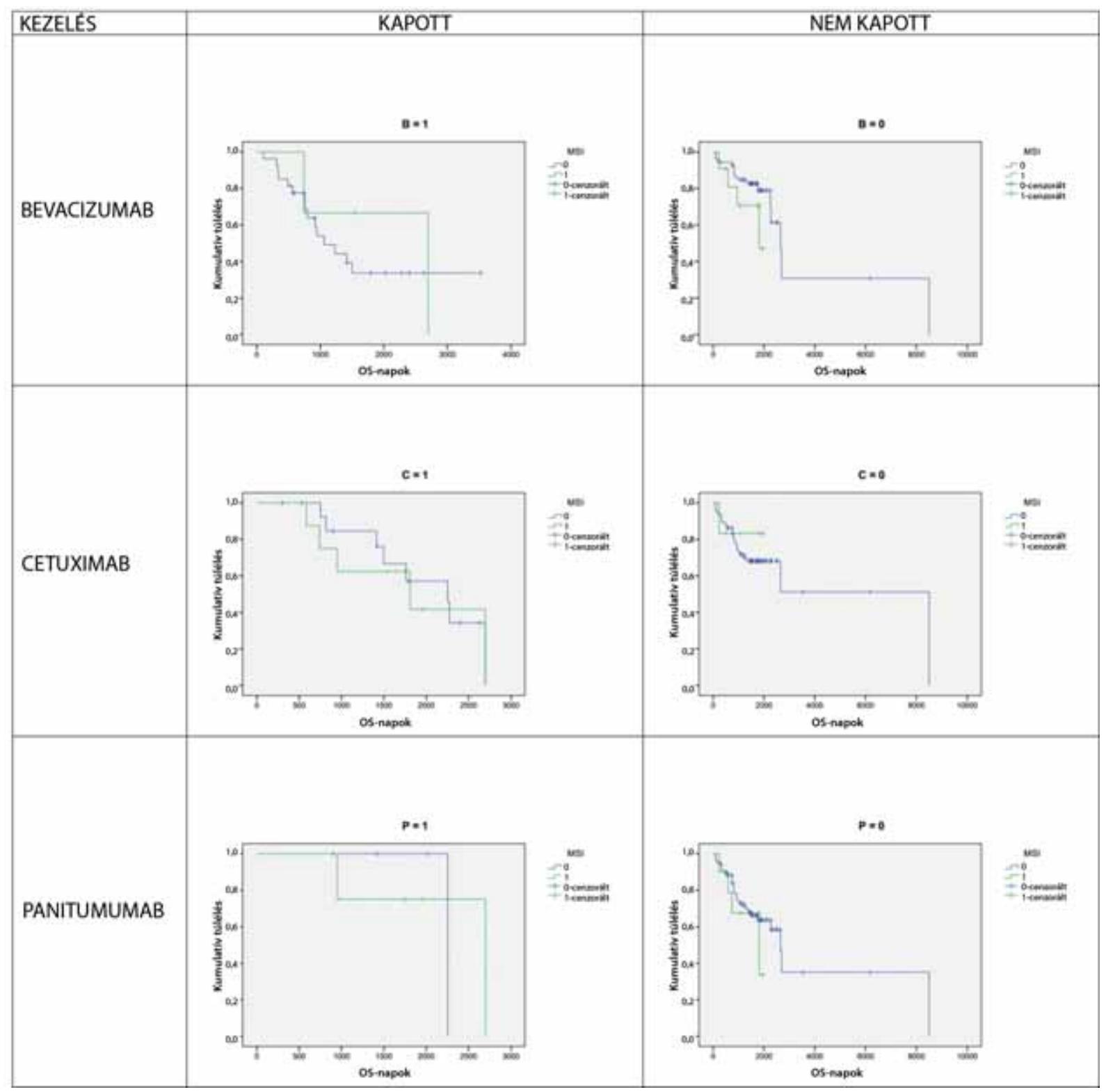

5. ábra (folyt.)

a primer tumort a metasztázisához képest más MMRstátusba sorolta. A tumoros progresszió során a primer tumortól a májmetasztázisig bekövetkező MMR-státusváltozásról eltérő vizsgálati eredmények születtek. Egyesek nagyobb arányban találtak MSI-t a primer tumorban [28, 29, 30], míg mások a hozzá tartozó májáttétben [31]. Ezt az eltérést több ok is magyarázhatja. Egyrészt technikai (fixálási faktorokból és festési eljárásból adódó) hiba vagy a vizsgált mikroszatellita-locusok különbözősége [31]; lehet valódi biológiai jelenség: a tumoros progresszió során fokozódó genetikai instabilitás és a metasztázisképződés során bekövetkező klonális szelekció $[32,33]$; ezenkívül más, még feltáratlan okok is állhatnak a háttérben. A mi vizsgálatunkban a primer tumorok és májmetasztázisaik között észlelt eltérést nem technikai okokra vezetjük vissza, megfelelő pozitív és negatív kontrollok alkalmazása mellett a TMA-eljárás al- kalmazását megbízhatónak tartjuk [34]. A technikai hiba lehetősége ellen szól a standardizált, automatizált immunhisztokémiai technika is, amelyet tanulmányunkban alkalmaztunk. A sporadikus MSI prognosztikai jelentőségéről vastagbélrákban az elmúlt években jelentek meg kisebb-nagyobb tanulmányok, többségükben arra a következtetésre jutva, hogy a hibás MMR-státus jobb prognózist jelent a DFS és OS tekintetében a mikroszatellita-stabil tumorokhoz viszonyítva $[8,35,36,37,38]$. Ezzel az általunk kapott eredmények nincsenek összhangban. A 122 követési adattal rendelkező betegünk relapsusmentes és teljes túlélését elemezve az MSI-státus nem bizonyult prognosztikus jelentőségünek. Klinikai szempontból nagyon fontos kérdés és az irodalomban is sokat vitatott, hogy az MSI-státus befolyásolja-e, és ha igen, hogyan az adjuvánsan kezelt vastagbélrákos betegek betegségmentes és össztúlélését. A legtöbb közle- 
mény a leggyakrabban alkalmazott 5-FU és az MSI-státus összefüggésével foglalkozik [39]. Egyes vizsgálatok szerint MSI-tumorok fokozottan szenzitívek 5-FU-kezelésre [40, 41 , 42], míg mások nem tapasztaltak terápiás válaszkülönbséget az MMR-státus függvényében [43]. Az elmúlt évek vizsgálati eredményei alapján egyre inkább elfogadottnak látszik, hogy a II-es és III-as stádiumú MSI vastagbélrákos betegek nem profitálnak az 5-FU-alapú kemoterápiából [17], viszont II-es stádiumú MSI colorectalis tumorok adjuváns 5-FU-kezelés mellett is fenntartják a jobb RFS-t és OS-t az MSS-tumorokhoz viszonyítva [44]. Néhány vizsgálat eredménye alapján azonban II-es és III-as stádiumú colorectalis carcinomás betegek MMR-státusát szükséges lenne meghatározni, mert az adjuvánsan adott 5-FU a $\mathrm{pT}_{3} \mathrm{~N}_{0}$ stádiumú MSIdaganatos betegekben ronthatja a betegségmentes és teljes túlélést $[18,19]$. Kilencvenhét betegünk esetében, ahol az onkológiai kezelés pontos adatai rendelkezésünkre álltak, azt tapasztaltuk, hogy sem a relapsusmentes, sem a teljes, sem a progressziómentes túléléshez viszonyítva nem volt prediktív az MMR-státus sem az 5-FU-, sem az oxaliplatin-, sem az irinotecan-, sem pedig a legújabb biológiai terápiák (bevacizumab, cetuximab, panitumumab) vonatkozásában. A mi elemzéseinkben az 5-FU-kezelt stage II és stage III esetekben sem tudtunk statisztikailag jelentős különbséget kimutatni az

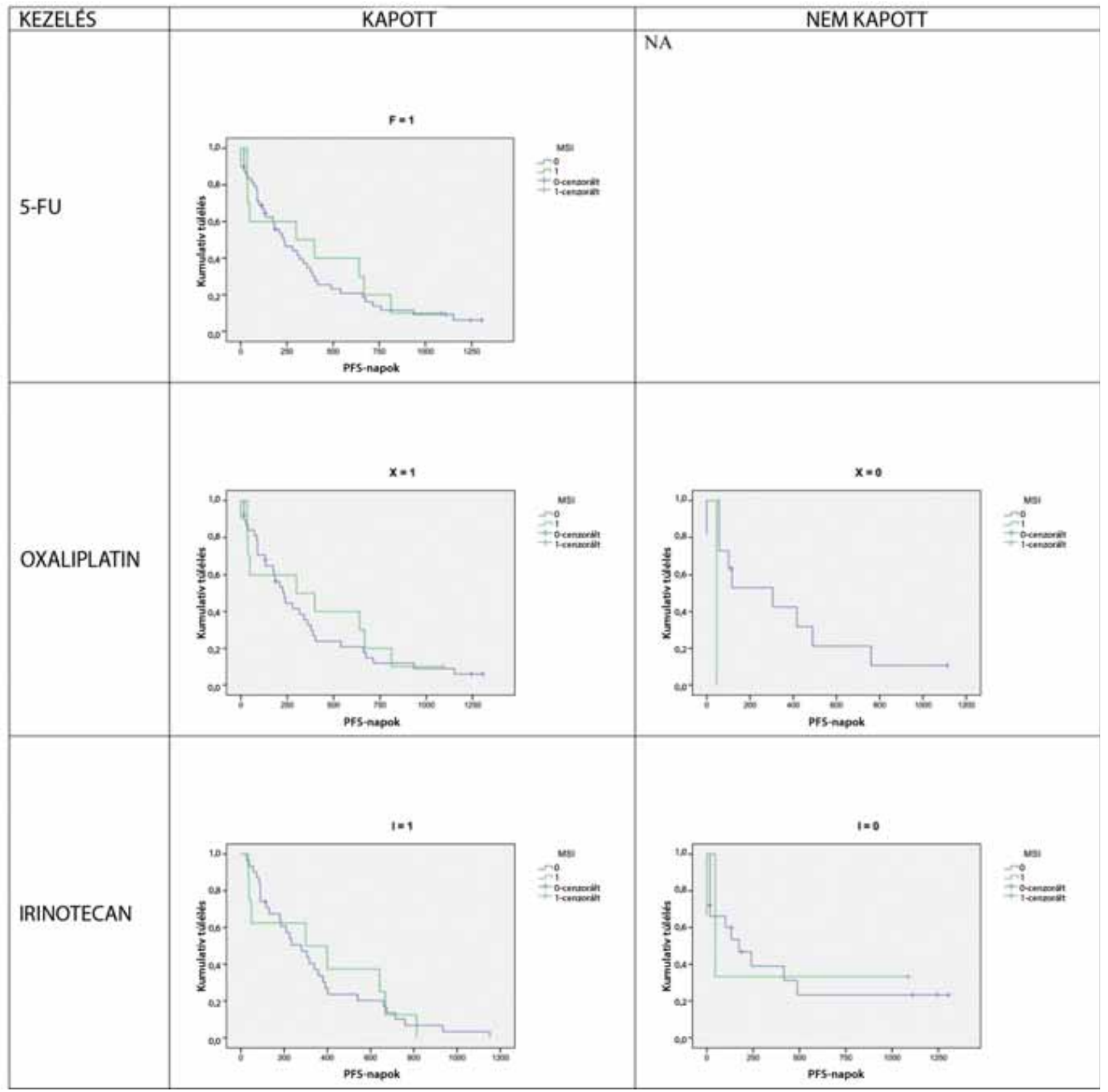




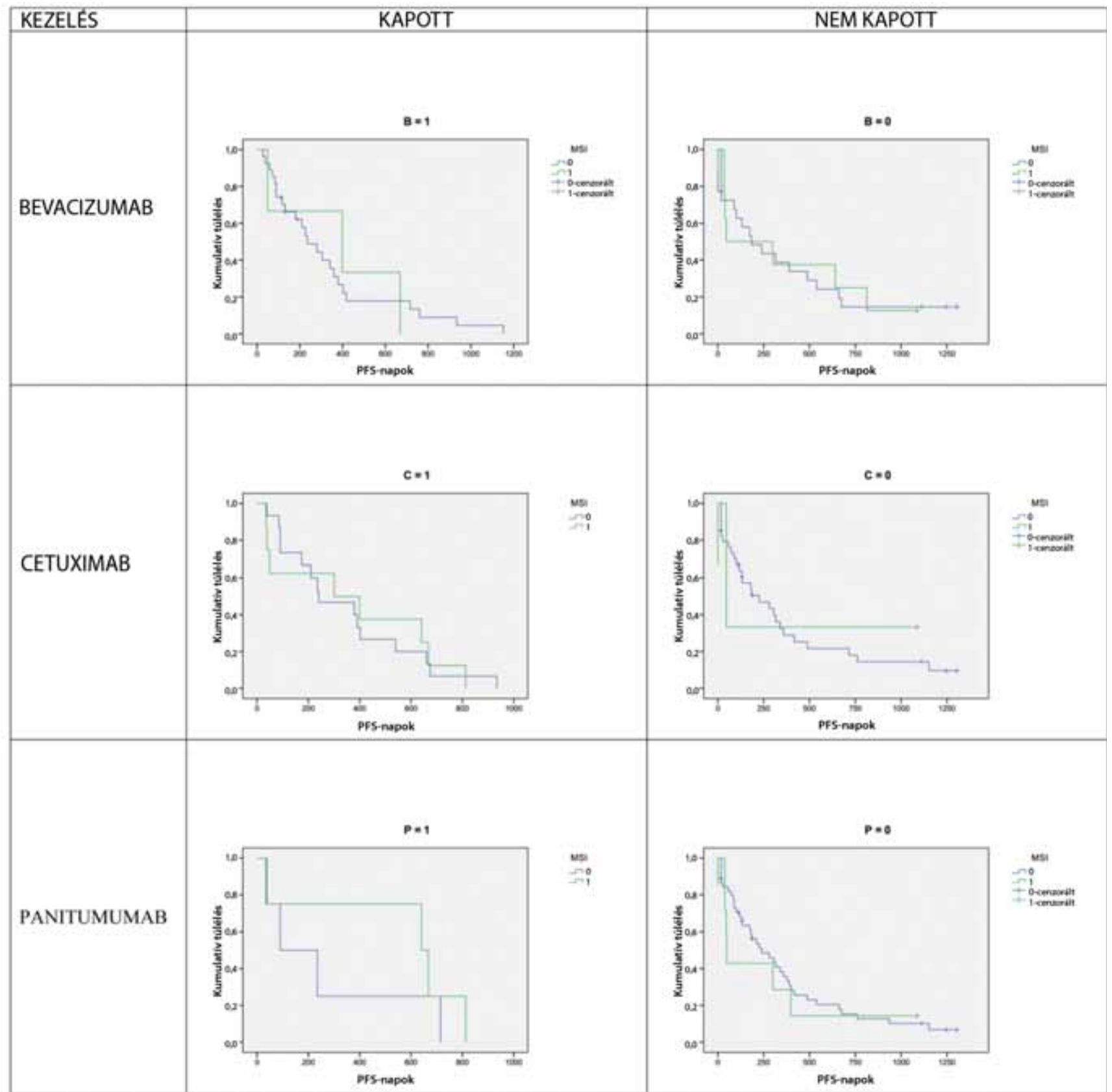

6. ábra (folyt.)

MSI- és MSS-tumorok között. Hozzá kell tennünk azonban, hogy a multimodális terápia és a több vonalban alkalmazott kombinált szerek alapján nem tudunk klinikai vizsgálatnak megfelelő homogén betegcsoportokat kialakítani felmésérünkhöz.

Vélhetően nagyobb esetszámú vizsgálatban komplex jelátviteli útvonalakban szereplő molekulák expressziója alapján felállított alcsoportok elemzésével a statisztikai erő növekedhet. Olyan patobiológiai faktorok, mint a BRAF-mutáció, alapvető szerepet játszanak az MSI-tumorok kórlefolyásában [45] és a kezelésre adott válaszának előrejelzésében [46], ezért vizsgálatunkat a betegszám növelése mellett többek között ezen mutáció elemzésével is ki szeretnénk egészíteni.
Anyagi támogatás: A kutatás a TAMOP 4.2.4. A/2-111-2012-0001 azonosítószámú Nemzeti Kiválóság Program - Hazai hallgatói, illetve kutatói személyi támogatást biztosító rendszer kidolgozása és múködtetése országos program címú kiemelt projekt keretében zajlott. A projekt az Európai Unió támogatásával, az Európai Szociális Alap társfinanszírozásával valósult meg.

Szerzői munkamegosztás: Á. E. I.: A betegek utánkövetési adatainak gyújtése és rendezése, szövetminták összegyüjtése, szöveti multiblokkok készítése, immunhisztokémiai reakciók értékelése, a kézirat megírása és szerkesztése. B. Zs., K. J., H. L.: A laboratórium biztosítása, kézirat megírása és szerkesztése. D. K., B. A.: 

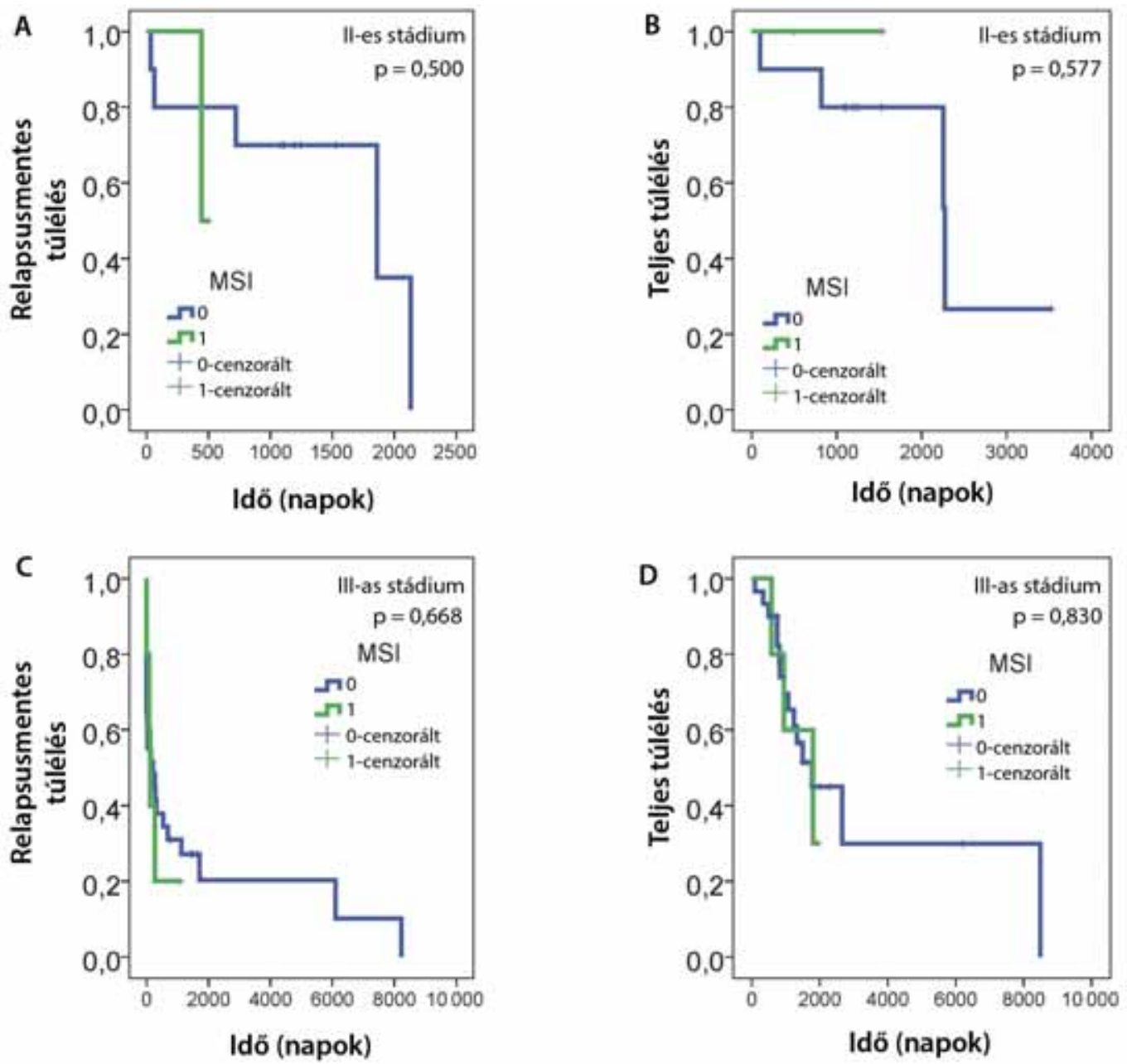

7. ábra | Az MSI- és MSS-daganatok a stádium és 5-FU-kezelés tükrében

A betegek utánkövetési adatainak biztosítása. B. Gy. A betegek posztoperatív kezelése és követése, utánkövetési adatok biztosítása. B. Zs., K. J., H. L.: A laboratórium biztosítása, kézirat megírása és szerkesztése. Sz. A. M.: A vizsgálat megtervezése és koordinálása, a szövetminták és az értékelt IHC ellenőrzése, statisztikai analízis, a kézirat megírása és szerkesztése. A cikk végleges változatát valamennyi szerző elolvasta és jóváhagyta.

Érdekeltségek: A szerzőknek nincsenek érdekeltségeik

\section{Köszönetnyilvánítás}

Köszönet illeti Azumah Erzsébetet a szövetminták feldolgozásában végzett segítókész munkájáért.

\section{Irodalom}

[1] Tusnády, G., Gaudi, I., Rejtó, L., et al.: Survival chances of Hungarian cancer patients in the National Cancer Registry. [A magyar daganatos betegek túlélési esélye a nemzeti rákregiszter adatai alapján.] Magy. Onkol., 2008, 52(4), 339-349. [Hungarian]
[2] Goel, A., Arnold, C. N., Niedzwiecki, D., et al.: Characterization of sporadic colon cancer by patterns of genomic instability. Cancer Res., 2003, 63(7), 1608-1614.

[3] Liefers, G. J., Tollenaar, R. A.: Cancer genetics and their application to individualised medicine. Eur. J. Cancer, 2002, 38(7), 872-879.

[4] Konishi, M., Kikuchi-Yanoshita, R., Tanaka, K., et al.: Molecular nature of colon tumors in hereditary nonpolyposis colon cancer, familial polyposis, and sporadic colon cancer. Gastroenterology, 1996, 111(2), 307-317.

[5] Aaltonen, L. A., Peltomäki, P., Leach, F. S., et al.: Clues to the pathogenesis of familial colorectal cancer. Science, 1993, 260(5109), 812-816.

[6] Kouraklis, G., Misiakos, E. P.: Hereditary nonpolyposis colorectal cancer (Lynch syndrome): criteria for identification and management. Dig. Dis. Sci., 2005, 50(2), 336-344.

[7] Yamamoto, H., Imai, K.: Microsatellite instability: an update. Arch. Toxicol., 2015, 89(6), 899-921.

[8] Popat, S., Hubner, R., Houlston, R. S.: Systematic review of microsatellite instability and colorectal cancer prognosis. J. Clin. Oncol., 2005, 23(3), 609-618.

[9] Bubb, V. J., Curtis, L. J., Cunningham, C., et al.: Microsatellite instability and the role of hMSH2 in sporadic colorectal cancer. Oncogene, 1996, 12(12), 2641-2649.

[10] Sinicrope, F. A., Foster, N. R., Yoon, H. H., et al.: Association of obesity with DNA mismatch repair status and clinical outcome in 
patients with stage II or III colon carcinoma participating in NCCTG and NSABP adjuvant chemotherapy trials. J. Clin. Oncol., 2012, 30(4), 406-412.

[11] Cicek, M. S., Lindor, N. M., Gallinger, S., et al.: Quality assessment and correlation of microsatellite instability and immunohistochemical markers among population- and clinic-based colorectal tumors results from the Colon Cancer Family Registry. J. Mol. Diagn., 2011, 13(3), 271-281.

[12] Kim, H., Jen, J., Vogelstein, B., et al.: Clinical and pathological characteristics of sporadic colorectal carcinomas with DNA replication errors in microsatellite sequences. Am. J. Pathol., 1994, 145(1), 148-156.

[13] Tejpar, S.: The multidisciplinary management of gastrointestinal cancer. The use of molecular markers in the diagnosis and treatment of colorectal cancer. Best Pract. Res. Clin. Gastroenterol., 2007, 21(6), 1071-1087.

[14] Gafa, R., Maestri, I., Matteuzzi, M., et al.: Sporadic colorectal adenocarcinomas with high-frequency microsatellite instability. Cancer, 2000, 89(10), 2025-2037.

[15] Carethers, J. M., Murali, B., Yang, B., et al.: Influence of race on microsatellite instability and CD8+ T cell infiltration in colon cancer. PLoS ONE, 2014, 9(6), e100461.

[16] Cascinu, S., Georgoulias, V., Kerr, D., et al.: Colorectal cancer in the adjuvant setting: perspectives on treatment and the role of prognostic factors. Ann. Oncol., 2003, 14 (Suppl. 2), ii25-ii29.

[17] Sargent, D. J., Marsoni, S., Monges, G., et al.: Defective mismatch repair as a predictive marker for lack of efficacy of fluorouracilbased adjuvant therapy in colon cancer. J. Clin. Oncol., 2010, 28(20), 3219-3226.

[18] Ribic, C. M., Sargent, D. J., Moore, M. J., et al.: Tumor microsatellite-instability status as a predictor of benefit from fluorouracilbased adjuvant chemotherapy for colon cancer. N. Engl. J. Med., 2003, 349(3), 247-257.

[19] Donada, M., Bonin, S., Barbazza, R., et al.: Management of stage II colon cancer - the use of molecular biomarkers for adjuvant therapy decision. BMC Gastroenterol., 2013, 13, 36.

[20] Boland, C. R., Goel, A.: Microsatellite instability in colorectal cancer. Gastroenterology, 2010, 138(6), 2073-2087. e3

[21] Lynch, H. T., Lynch, J. F., Lynch, P. M., et al.: Hereditary colorectal cancer syndromes: molecular genetics, genetic counseling, diagnosis and management. Fam. Cancer, 2008, 7(1), 27-39.

[22] Lynch, H. T., Smyrk, T. C., Watson, P., et al.: Genetics, natural history, tumor spectrum, and pathology of hereditary nonpolyposis colorectal cancer: an updated review. Gastroenterology, $1993,104(5), 1535-1549$

[23] Gryfe, R., Kim, H., Hsieh, E. T., et al.: Tumor microsatellite instability and clinical outcome in young patients with colorectal cancer. N. Engl. J. Med., 2000, 342(2), 69-77.

[24] Al-Sobaily, S., Biankin, A., Leong, R., et al.: Molecular pathways in colorectal cancer. J. Gastroenterol. Hepatol., 2012, 27(9), 1423-1431.

[25] Abdel-Rahman, W. M., Georgiades, I. B., Curtis, L. J., et al.: Role of BAX mutations in mismatch repair-deficient colorectal carcinogenesis. Oncogene, 1999, 18(12), 2139-2142.

[26] Barnetson, R., Jass, J., Tse, R., et al.: Mutations associated with microsatellite unstable colorectal carcinomas exhibit widespread intratumoral heterogeneity. Genes Chromosomes Cancer, 2000, 29(2), 130-136.

[27] Chung, Y. J., Park, S. W., Song, J. M., et al.: Evidence of genetic progression in human gastric carcinomas with microsatellite instability. Oncogene, 1997, 15(14), 1719-1726.

[28] Ishimaru, G., Adachi, J., Shiseki, M., et al.: Microsatellite instability in primary and metastatic colorectal cancers. Int. J. Cancer, $1995,64(3), 153-157$

[29] Blaker, H., Graf, M., Rieker, R. J., et al.: Comparison of losses of heterozygosity and replication errors in primary colorectal carcinomas and corresponding liver metastases. J. Pathol., 1999, $188(3), 258-262$.
[30] Barnetson, R., Eckstein, R., Robinson, B., et al.: There is no increase in frequency of somatic mutations in metastases compared with primary colorectal carcinomas with microsatellite instability. Genes Chromosomes Cancer, 2003, 38(2), 149-156.

[31] Chen, W. S., Chen, J. Y., Liu, J. M., et al.: Microsatellite instability in sporadic-colon-cancer patients with and without liver metastases. Int. J. Cancer, 1997, 74(4), 470-474.

[32] Chong, J. M., Fukayama, M., Hayashi, Y., et al.: Microsatellite instability in the progression of gastric carcinoma. Cancer Res., 1994, 54(17), 4595-4597.

[33] Merlo, A., Mabry, M., Gabrielson, E., et al.: Frequent microsatellite instability in primary small cell lung cancer. Cancer Res., 1994, 54(8), 2098-2101.

[34] McConechy, M. K., Talhouk, A., Li-Chang, H. H., et al.: Detection of DNA mismatch repair (MMR) deficiencies by immunohistochemistry can effectively diagnose the microsatellite instability (MSI) phenotype in endometrial carcinomas. Gynecol. Oncol., 2015, 137(2), 306-310.

[35] Korphaisarn, K., Pongpaibul, A., Limwongse, C., et al.: Deficient DNA mismatch repair is associated with favorable prognosis in Thai patients with sporadic colorectal cancer. World J. Gastroenterol., 2015, 21(3), 926-934.

[36] Hong, S. P., Min, B. S., Kim, T. I., et al.: The differential impact of microsatellite instability as a marker of prognosis and tumour response between colon cancer and rectal cancer. Eur. J. Cancer, 2012, 48(8), 1235-1243.

[37] Roth, A. D., Delorenzi, M., Tejpar, S., et al.: Integrated analysis of molecular and clinical prognostic factors in stage II/III colon cancer. J. Natl. Cancer Inst., 2012, 104(21), 1635-1646.

[38] Merok, M. A., Ablquist, T., Røyrvik, E. C., et al.: Microsatellite instability has a positive prognostic impact on stage II colorectal cancer after complete resection: results from a large, consecutive Norwegian series. Ann. Oncol., 2013, 24(5), 1274-1282.

[39] Des Guetz, G., Schischmanoff, O., Nicolas, P., et al.: Does microsatellite instability predict the efficacy of adjuvant chemotherapy in colorectal cancer? A systematic review with meta-analysis. Eur. J. Cancer, 2009, 45(10), 1890-1896.

[40] Elsaleh, H., Joseph, D., Grieu, F., et al.: Association of tumour site and sex with survival benefit from adjuvant chemotherapy in colorectal cancer. Lancet, 2000, 355(9217), 1745-1750.

[41] Hemminki, A., Mecklin, J. P., Järvinen, H., et al.: Microsatellite instability is a favorable prognostic indicator in patients with colorectal cancer receiving chemotherapy. Gastroenterology, 2000, 119(4), 921-928.

[42] Jover, R., Zapater, P., Castells, A., et al.: The efficacy of adjuvant chemotherapy with 5 -fluorouracil in colorectal cancer depends on the mismatch repair status. Eur. J. Cancer, 2009, 45(3), 365373.

[43] Kim, G. P., Colangelo, L. H., Wieand, H. S., et al.: Prognostic and predictive roles of high-degree microsatellite instability in colon cancer: a National Cancer Institute-National Surgical Adjuvant Breast and Bowel Project Collaborative Study. J. Clin. Oncol., 2007, 25(7), 767-772.

[44] Klingbiel, D., Saridaki, Z., Roth, A. D., et al.: Prognosis of stage II and III colon cancer treated with adjuvant 5-fluorouracil or FOLFIRI in relation to microsatellite status: results of the PETACC-3 trial. Ann. Oncol., 2015, 26(1), 126-132.

[45] Neumann, J., Reu, S., Kirchner, T.: Prognostic marker profiles for risk of distant metastases in colorectal cancer. Pathologe, 2012, 33(1), 39-44.

[46] Ooki, A., Akagi, K., Yatsuoka, T., et al.: Combined microsatellite instability and BRAF gene status as biomarkers for adjuvant chemotherapy in stage III colorectal cancer. J. Surg. Oncol., 2014, 110(8), 982-988.

(Ágoston Emese Irma dr., Budapest, Üllói út 78., 1082 e-mail: emeseagoston@gmail.com) 